Adrian MOSLER ${ }^{1}$, Arkadiusz TRĄBKA $^{2}$

Opiekun naukowy: Arkadiusz TRĄBKA ${ }^{2}$

DOI: https://doi.org/10.53052/9788366249837.35

\title{
ANALIZA NUMERYCZNA STEROWANIA RUCHAMI ROBOCZYMI ŻURAWIA WIEŻOWEGO
}

\begin{abstract}
Streszczenie: Przedstawiono model symulacyjny żurawia wieżowego, opracowanie modelu układu regulacji ruchami roboczymi żurawia oraz analizę numeryczną przenoszenia ładunku według zadanych trajektorii ruchu. Ocenie poddano skuteczność zaprojektowanego układu regulacji w odwzorowaniu zadanych trajektorii dla dwóch znacznie różniących się prędkości ruchów roboczych.
\end{abstract}

Słowa kluczowe: żuraw wieżowy, model symulacyjny, trajektoria ruchu ładunku, układ regulacji

\section{NUMERICAL ANALYSIS OF CONTROL OF TOWER CRANE WORKING MOVEMENTS}

Summary: A simulation model of a tower crane, as well as the development of a model of a control system for working movements and numerical analysis of a load transfer according to the given trajectories of movement were presented. The effectiveness of the designed control system in mapping the set trajectories for two significantly different speeds of working movements was assessed.

Keywords: tower crane, simulation model, trajectory of load movement, control system

\section{Wprowadzenie}

Żurawie wieżowe najczęściej użytkowane są na placach budów, a transport ładunków odbywa się w ograniczonej licznymi przeszkodami przestrzeni [1]. Od operatorów żurawi wymaga się, aby przeniesienie ładunku odbyło się w jak najkrótszym czasie, jednocześnie stawia się wymagania dotyczące minimalizacji jego wahań tak, aby ruch ładunku jak najmniej odbiegał od zadanej trajektorii. Doświadczeni operatorzy realizują powyższe zadania poprzez odpowiednie uruchamianie poszczególnych

\footnotetext{
${ }^{1}$ Akademia Techniczno-Humanistyczna, Wydział Budowy Maszyn i Informatyki, Automatyka i Robotyka, email: master9500@interia.pl

${ }^{2}$ dr inż., Akademia Techniczno-Humanistyczna, Wydział Budowy Maszyn i Informatyki, email: atrabka@ath.bielsko.pl
} 
napędów żurawia. Aby jednak rozwiązać problem ograniczenia wahań ładunku, konieczne jest zastosowanie wspomagającego te czynności układu regulacji. Doboru układu regulacji dokonuje się najczęściej na podstawie analizy numerycznej modelu obliczeniowego żurawia [2, 3, 4].

W celu zwiększenia wydajności oraz bezpieczeństwa pracy żurawi wieżowych podejmuje się także działania mające na celu całkowite zautomatyzowanie ich pracy $[5,6]$.

W niniejszej pracy za cel przyjęto wykonanie modelu symulacyjnego żurawia wieżowego, opracowanie modelu układu regulacji jego ruchami roboczymi oraz przeprowadzenie analiz przenoszenia ładunku według zadanych trajektorii ruchu.

\section{Model symulacyjny żurawia wieżowego}

Za podstawę do opracowania modelu symulacyjnego przyjęto konstrukcję żurawia wieżowego stacjonarnego $\mathrm{z}$ wysięgnikiem wodzakowym, górnoobrotowego o maksymalnym wysięgu $37 \mathrm{~m}$ i wysokości podnoszenia $25 \mathrm{~m}$. Przed przystąpieniem do modelowania podzielono konstrukcję na człony: podstawę wraz $\mathrm{z}$ wieżą, wysięgnik $\mathrm{z}$ przeciwwagą, wózek oraz zblocze hakowe. Poszczególne człony konstrukcji zamodelowano w programie Autodesk Inventor, przyjmując za podstawę ich opracowania zamieszczone w internecie dane techniczne, a także modele geometryczne udostępnione w [7]. Poszczególne człony wyeksportowano następnie do formatu STEP, zapisując każdy z nich jako pojedynczą bryłę przy użyciu tzw. komponentów pochodnych.

Model symulacyjny (rys. 1) opracowano w programie ADAMS, importując modele geometryczne członów (zapisanych jako komponenty pochodne), a następnie łącząc je w pary kinematyczne przy użyciu połączeń zapewniających odwzorowanie rzeczywistej ruchliwości członów.

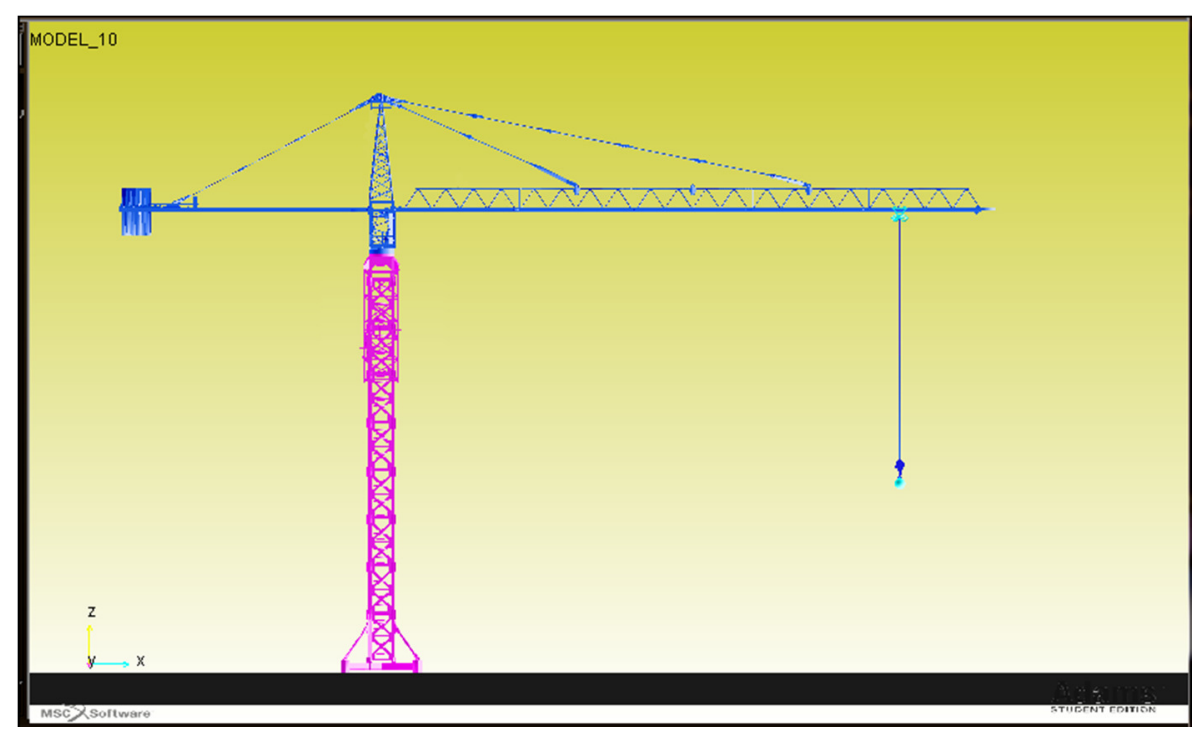

Rysunek 1. Model symulacyjny żurawia wieżowego 
Połączenie wózka ze zbloczem hakowym zrealizowano narzędziem Discrete Flexible Link, przy użyciu którego zdefiniowano jedenasto-segmentowe złącze podatne imitujące linę. Każdemu z członów przyporządkowano masy oraz masowe momenty bezwładności wyliczone w programie Autodesk Inventor (tabela 1).

Tabela 1. Masy i masowe momenty bezwładności członów żurawia

\begin{tabular}{|l|c|c|c|c|}
\hline \multicolumn{1}{|c|}{ Człon żurawia } & Masa & \multicolumn{3}{c|}{ Masowe momenty bezwładności } \\
\hline & {$[\mathrm{kg}]$} & $\mathrm{J}_{\mathrm{xx}}\left[\mathrm{kgm}^{2}\right]$ & $\mathrm{J}_{\mathrm{yy}}\left[\mathrm{kgm}^{2}\right]$ & $\mathrm{J}_{\mathrm{zz}}\left[\mathrm{kgm}^{2}\right]$ \\
\hline Wieża z podstawą & 49929 & 4543934 & 4551415 & 127338 \\
\hline Wysięgnik z przeciwwagą & 77482 & 275971 & 16973912 & 16744348 \\
\hline Wózek & 521 & 247.7 & 89.6 & 214.3 \\
\hline Hak & 214 & 14.8 & 17.3 & 3.2 \\
\hline
\end{tabular}

Opracowując model symulacyjny przyjęto pewne założenia upraszczające [8]:

- $\quad$ wszystkie człony potraktowano jako idealnie sztywne,

- pominięto luzy i tarcie w połączeniach członów,

- pominięto oddziaływania zewnętrzne typu parcie wiatru, zmiany temperatury, występowanie dodatkowych sił zewnętrznych.

Podparcie modelu zrealizowano poprzez odebranie wszystkich stopni swobody w miejscu połączenia podstawy z podłożem.

Jako wymuszenia ruchów roboczych zastosowano wektor siły dla napędu wózka w jego ruchu postępowym względem wysięgnika oraz wektor momentu dla napędu wysięgnika w jego ruchu obrotowym względem wieży.

Wartości siły i momentu napędowego wyznaczano w układzie regulacji, w programie Matlab/Simulink, na podstawie rejestrowanych w programie ADAMS wielkości, takich jak: przemieszczenie wózka, obrót wysięgnika, prędkość wózka, prędkość kątowa wysięgnika, przyspieszenie wózka, przyspieszenie kątowe wysięgnika oraz wychylenie kątowe ładunku w płaszczyznach XZ i YZ. W celu zapewnienia komunikacji pomiędzy programami, zarówno siłę i moment napędowy, jak i wszystkie z wymienionych wielkości kinematycznych zapisano jako zmienne stanu. Następnie przy użyciu modułu ADAMS/Control i okna dialogowego PlantExport poszczególne zmienne pogrupowano na sygnały wejściowe i wyjściowe, określono sposób komunikacji pomiędzy programami, po czym wygenerowano pliki modelu symulacyjnego możliwe do zaimportowania w programie Matlab/Simulink.

\section{Opracowanie modelu układu regulacji ruchami roboczymi żurawia}

Model układu regulacji ruchami roboczymi żurawia opracowano w programie Matlab/Simulink. Za podstawę opracowywanego układu przyjęto blok adams_sub (sub od angielskiego subsystem), stanowiący podukład tworzonego układu regulacji. Blok adams_sub zawiera zarówno model dynamiczny żurawia (blok ADAMS Plant), jak i wszystkie zdefiniowane w programie ADAMS sygnały wejściowe i wyjściowe (rys. 2). 


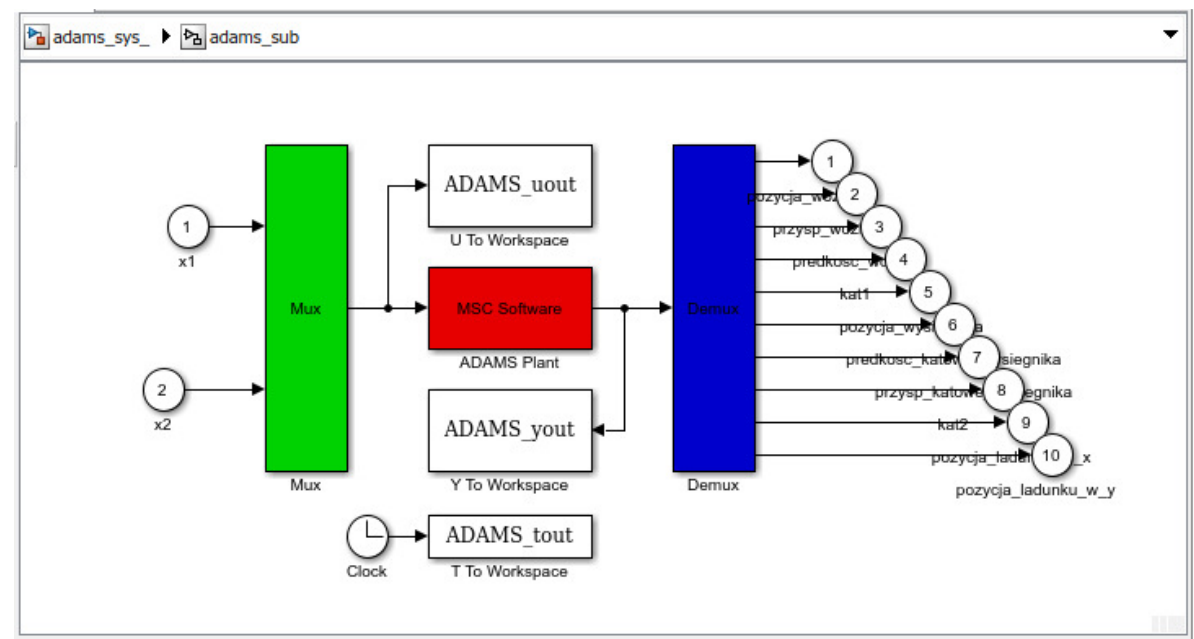

Rysunek 2. Struktura bloku adams_sub

Sygnałami wejściowymi do układu regulacji są wyjścia z modelu symulacyjnego, natomiast sygnałami wyjściowymi $\mathrm{z}$ układu regulacji są wejścia do modelu symulacyjnego (rys. 3).

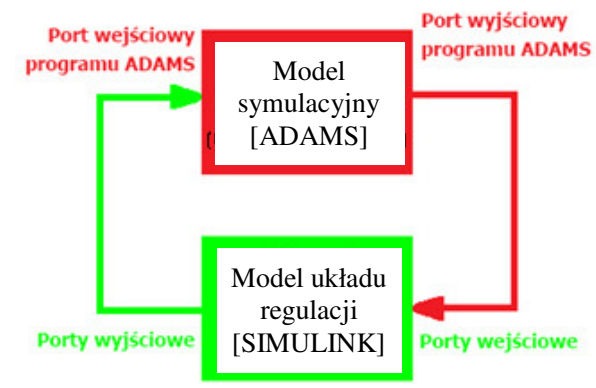

Rysunek 3. Ogólny schemat komunikacji pomiędzy modelem symulacyjnym a modelem uktadu regulacji

Układ regulacji (rys. 4) opracowano w oparciu o zasadę zadawania pożądanych wartości sygnałów i porównywania ich z sygnałami zwrotnymi odczytywanymi z modelu symulacyjnego.

Jako sygnały zadane przyjęto przemieszczenie wózka (funkcja pozycji wózka na rys. 4), obrót wysięgnika (funkcja pozycji wysięgnika na rys. 4) oraz wychylenie liny od pionu w płaszczyznach XZ (zadany kąt 1 na rys. 4) i YZ (zadany kąt 2 na rys. 4).

Wychylenie liny od pionu opisano kątami jakie tworzy lina z płaszczyzną, w której porusza się wysięgnik. Przyjęto, że kąty te powinny wynosić $90^{\circ}$.

Zadane przebiegi przemieszczenia wózka i obrotu wysięgnika wyznaczono rozwiązując odwrotne zadanie kinematyki $[9,10]$. W wyniku rozwiązania odwrotnego zadania kinematyki otrzymano równania (1) i (2), które umożliwiają określenie odpowiednio odległości wózka od osi obrotu wysięgnika $\left(\mathrm{d}_{3}\right)$ oraz kąta obrotu wysięgnika względem wieży $(\theta)$ w funkcji zadanych współrzędnych ładunku 
$(\mathrm{X}, \mathrm{Y})$, które dla każdej z rozpatrywanych trajektorii jego ruchu należy zapisać przy użyciu odpowiednio dobranych zależności analitycznych.

$$
\begin{aligned}
& d_{3}=\sqrt{X^{2}+Y^{2}} \\
& \theta=\left\{\begin{array}{c}
\arccos \left(\frac{X}{\sqrt{X^{2}+Y^{2}}}\right), \text { dla } Y \geq 0 \\
-\arccos \left(\frac{X}{\sqrt{X^{2}+Y^{2}}}\right), \text { dla } Y<0
\end{array}\right.
\end{aligned}
$$

gdzie: $\quad \mathrm{d}_{3}$ - odległość wózka od osi obrotu wysięgnika mierzona wzdłuż wysięgnika; $\theta$ - kąt obrotu wysięgnika względem wieży; X, Y - współrzędne ładunku w układzie odniesienia o początku w osi obrotu wysięgnika.

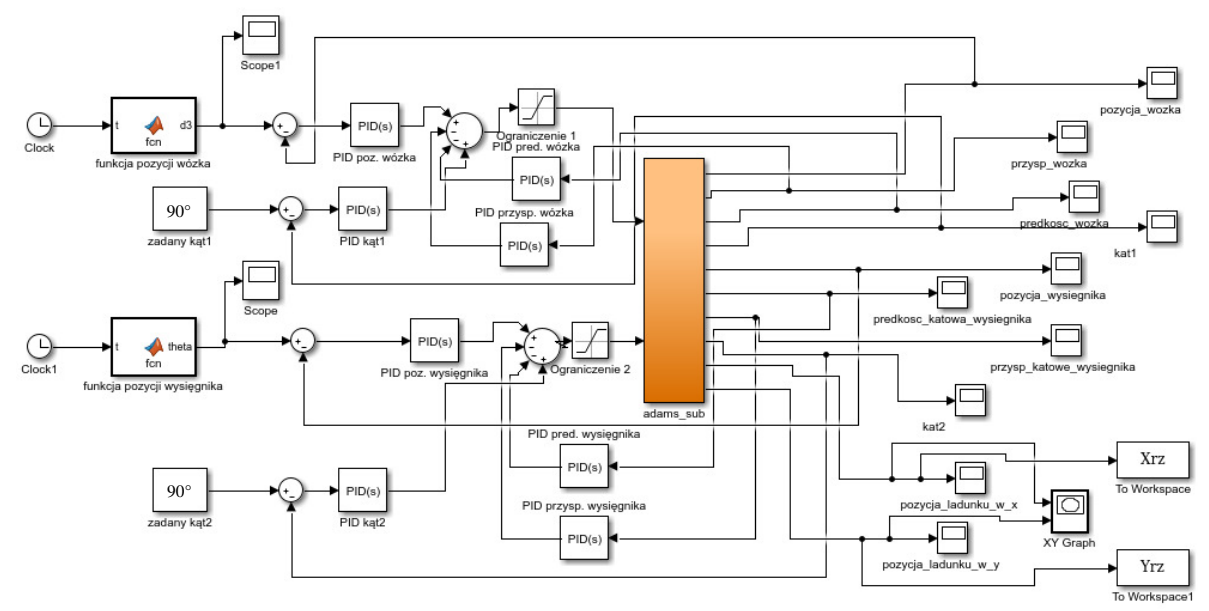

Rysunek 4. Schemat blokowy modelu układu regulacji ruchami roboczymi żurawia wieżowego

Sygnały wyjściowe $\mathrm{z}$ zaprojektowanego układu regulacji ( $x 1$ oraz $x 2$ na rys. 2) wyznaczano $\mathrm{w}$ funkcji uchybów, czyli różnic pomiędzy pożądanymi wartościami zadanymi a sygnałami zwrotnymi z modelu symulacyjnego, przy użyciu czterech regulatorów proporcjonalno-całkująco-różniczkujących (PID).

W celu poprawy jakości regulacji użyto dodatkowych czterech regulatorów PID. Dodatkowe regulatory zastosowano w celu uwzględnienia wpływu prędkości i przyspieszenia, odpowiednio wózka względem wysięgnika oraz wysięgnika względem wieży, na wartości sygnałów wyjściowych (siły i momentu obrotowego) przekazywanych do członów wykonawczych realizujących ruchy robocze żurawia, tzn. przemieszczenie wózka wzdłuż wysięgnika oraz obrót wysięgnika względem wieży. Nastawy regulatorów dobrano wstępnie metodą prób i błędów (metodą inżynierską), a następnie poddawano dodatkowej korekcji w celu uzyskania pożądanych dokładności odwzorowywania zadanych trajektorii ładunku. Nastawy regulatorów modyfikowano tak, aby maksymalne odchylenie od trajektorii zadanych nie przekraczało $50 \mathrm{~cm}$. 


\section{Analiza ruchu ładunku dla zadanych trajektorii}

Analizy numeryczne sterowania ruchami roboczymi żurawia w celu odwzorowania zadanych trajektorii ruchu ładunku przeprowadzono dla ładunku o masie $1500 \mathrm{~kg}$, zawieszonego na linie o długości $13 \mathrm{~m}$. Analizie poddano dwie trajektorie ruchu ładunku - prostoliniową oraz sinusoidalną. Dla każdej z rozpatrywanych trajektorii zadane współrzędne ładunku (X, Y) opisano przy użyciu zależności analitycznych. $\mathrm{W}$ pierwszej kolejności analizie poddano prostoliniowy ruch ładunku pomiędzy punktami A i B o współrzędnych $\mathrm{X}_{\mathrm{A}}=30 \mathrm{~m}, \mathrm{Y}_{\mathrm{A}}=2 \mathrm{~m}, \mathrm{X}_{\mathrm{B}}=19.5 \mathrm{~m}, \mathrm{Y}_{\mathrm{B}}=12.65 \mathrm{~m}$. Analizy przeprowadzono dla dwóch wartości czasu, w którym ładunek ma zostać przemieszczony z punktu A do punktu B. Na rys. 5 porównano trajektorię zadaną i otrzymaną z symulacji dla ruchu trwającego $45 \mathrm{~s}$, natomiast na rys. 6 zamieszczono porównanie trajektorii dla ruchu trwającego $25 \mathrm{~s}$.
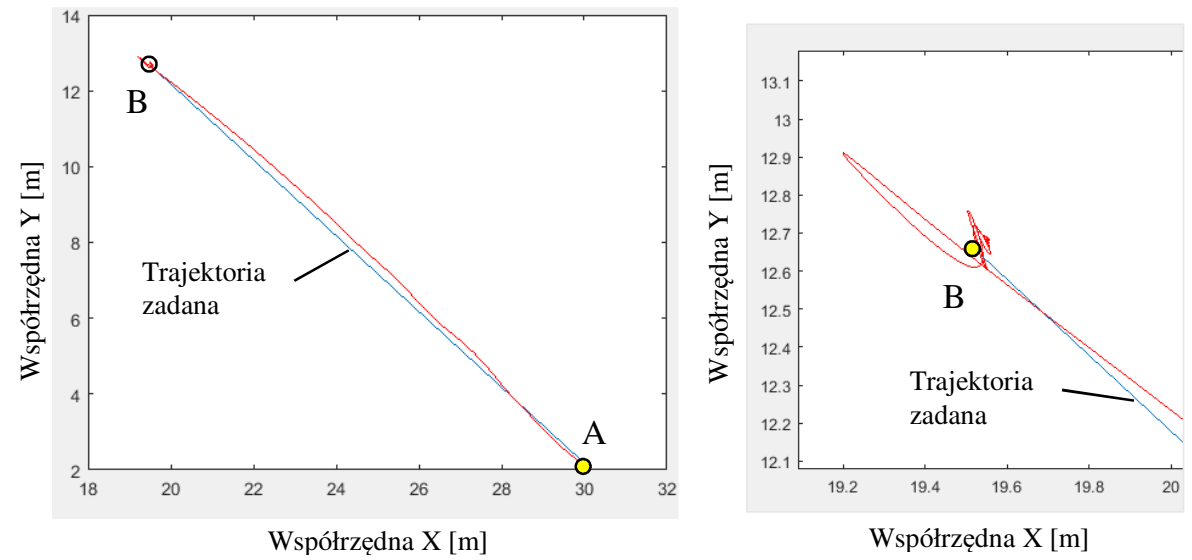

Rysunek 5. Porównanie trajektorii zadanej (kolor niebieski) i otrzymanej z symulacji (kolor czerwony) dla ruchu prostoliniowego trwajacego $45 \mathrm{~s}$
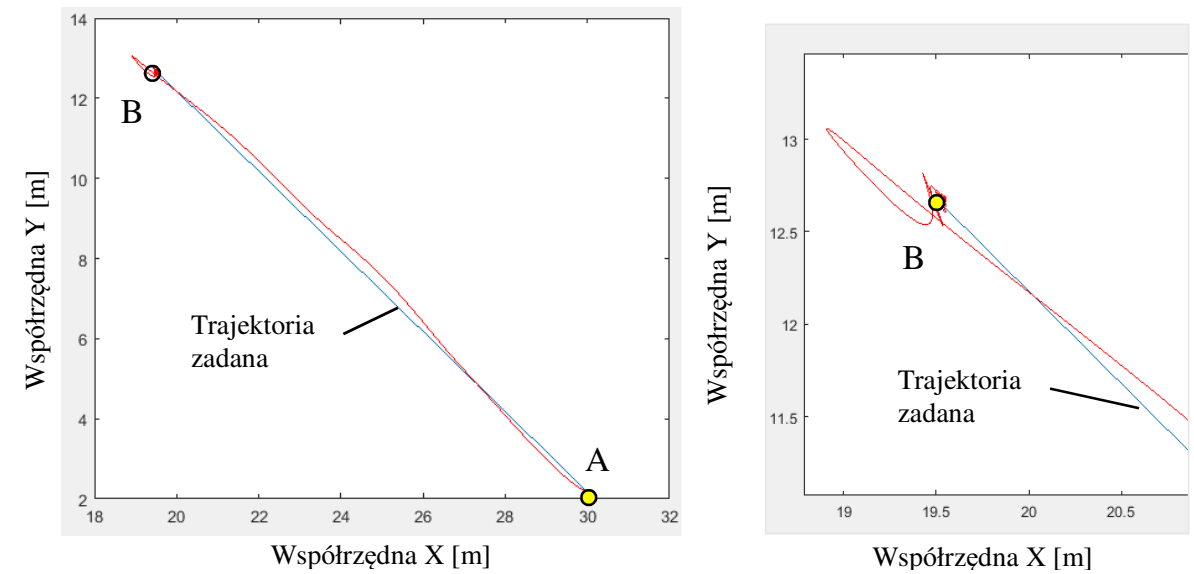

Rysunek 6. Porównanie trajektorii zadanej (kolor niebieski) i otrzymanej z symulacji (kolor czerwony) dla ruchu prostoliniowego trwajacego $25 \mathrm{~s}$ 
Stwierdzono, że dla ruchu prostoliniowego trajektoria otrzymana z symulacji (rys. 5 i 6), niezależnie od czasu trwania ruchu, nieznacznie tylko odbiega od zadanej. Maksymalne odchylenie ładunku od trajektorii zadanej dla ruchu trwającego $45 \mathrm{~s}$ wyniosło $24 \mathrm{~cm}$, natomiast dla ruchu trwającego $25 \mathrm{~s}$ było tylko nieco większe i wyniosło $28 \mathrm{~cm}$. Zarazem, w obu analizowanych przypadkach stwierdzono, że po osiągnięciu punktu końcowego ładunek nie zatrzymuje się, ale pod wpływem sił bezwładności wykonuje wahania w pobliżu punktu końcowego.

Na rys. 7 porównano trajektorie otrzymane z symulacji dla różnych czasów trwania ruchu pomiędzy punktami A i B.

Stwierdzono, że ze wzrostem prędkości roboczej żurawia nasilają się wahania ładunku w punkcie końcowym ruchu, a czas potrzebny na wygaszenie tych wahań wydłuża się z 45 do 70 sekund.
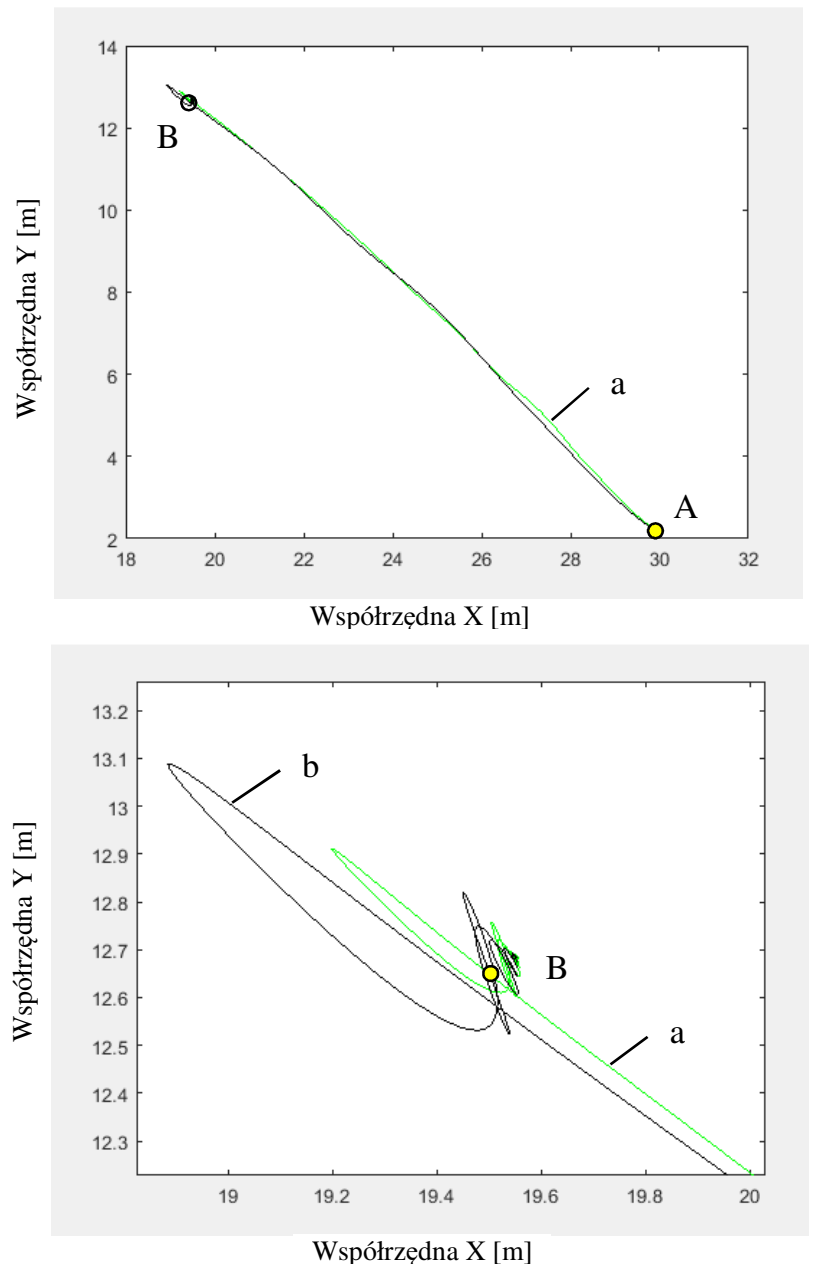

Rysunek 7. Porównanie trajektorii otrzymanych z symulacji dla ruchu prostoliniowego trwajacego: a) 45 s (linia koloru zielonego) i b) 25 s (linia koloru czarnego) 
Drugą analizowaną trajektorią był ruch sinusoidalny o amplitudzie $4 \mathrm{~m}$, realizowany pomiędzy punktami A i B (współrzędne punktów jak dla ruchu prostoliniowego). Na rys. 8 porównano trajektorię zadaną i otrzymaną z symulacji dla ruchu trwającego $70 \mathrm{~s}$, natomiast na rys. 9 zamieszczono porównanie trajektorii dla ruchu trwającego $40 \mathrm{~s}$.
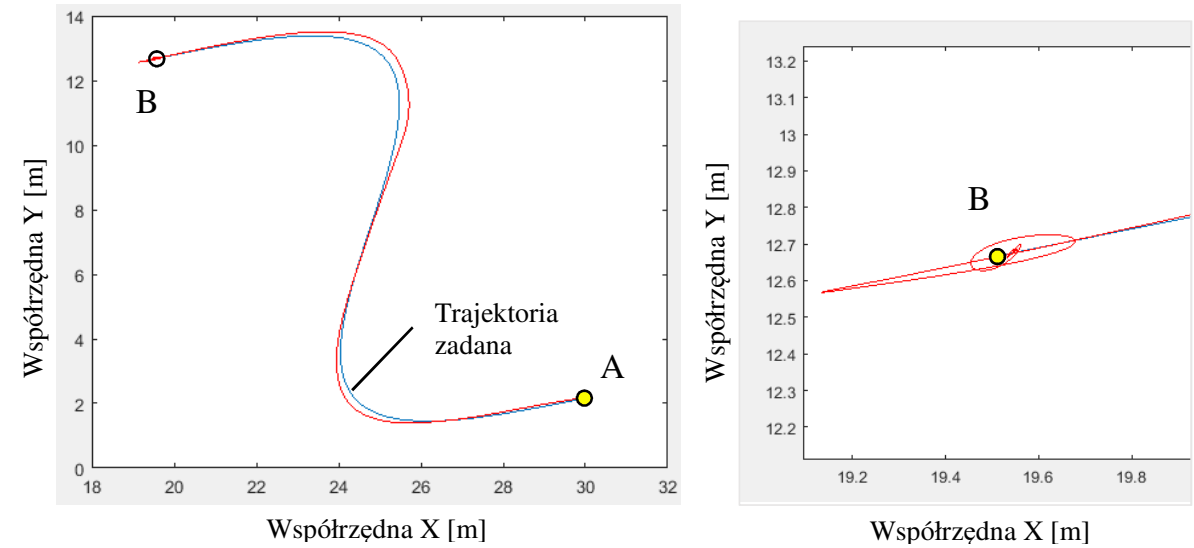

Rysunek 8. Porównanie trajektorii zadanej (kolor niebieski) i otrzymanej z symulacji (kolor czerwony) dla ruchu sinusoidalnego trwajacego $70 \mathrm{~s}$
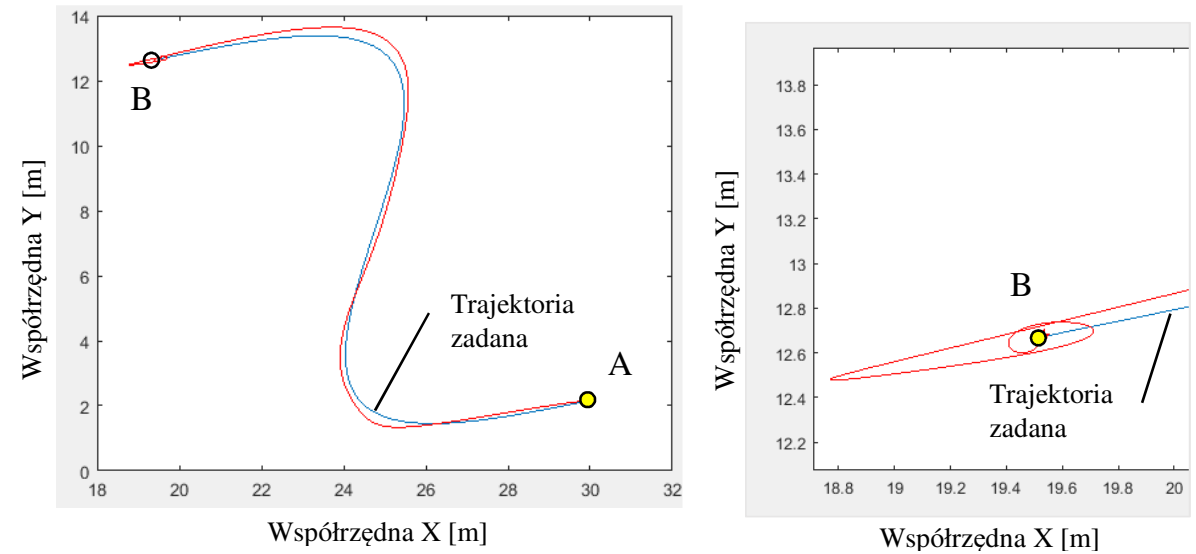

Rysunek 9. Porównanie trajektorii zadanej (kolor niebieski) i otrzymanej z symulacji (kolor czerwony) dla ruchu sinusoidalnego trwajacego $40 \mathrm{~s}$

W przypadku ruchu o trajektorii sinusoidalnej, podobnie jak w ruchu po linii prostej stwierdzono, że niezależnie od czasu trwania ruchu trajektoria otrzymana z symulacji tylko nieznacznie odbiega od zadanej, a po osiągnięciu punktu końcowego ładunek nie zatrzymuje się, ale pod wpływem sił bezwładności wykonuje wahania w pobliżu tego punktu. Maksymalne odchylenie ładunku od trajektorii zadanej dla ruchu sinusoidalnego trwającego $70 \mathrm{~s}$ wyniosło $26 \mathrm{~cm}$, natomiast dla ruchu trwającego $40 \mathrm{~s}$ wyniosło $33 \mathrm{~cm}$. Oznacza to, że nawet przy większych prędkościach ruchów 
roboczych maksymalne odchylenie ładunku od trajektorii zadanej było znacznie mniejsze od dopuszczalnego.

Na rys. 10 porównano trajektorie otrzymane z symulacji dla różnych czasów trwania ruchu. W przypadku trajektorii sinusoidalnej krzywizna toru powoduje, że ze wzrostem prędkości ruchów roboczych, pod wpływem sił odśrodkowych występują większe różnice $\mathrm{w}$ odwzorowaniu trajektorii zadanej niż w ruchu po linii prostej. Ponadto, tak jak w przypadku ruchu prostoliniowego, także po zakończeniu ruchu o trajektorii sinusoidalnej ładunek nie zatrzymuje się w punkcie końcowym, ale pod wpływem sił bezwładności porusza się dalej zataczając elipsy w otoczeniu punktu końcowego. Wielkość obserwowanych przemieszczeń ładunku względem punktu końcowego jest proporcjonalna do poprzedzających tę fazę ruchu prędkości pracy napędów żurawia podczas przenoszenia ładunku pomiędzy punktami A i B.
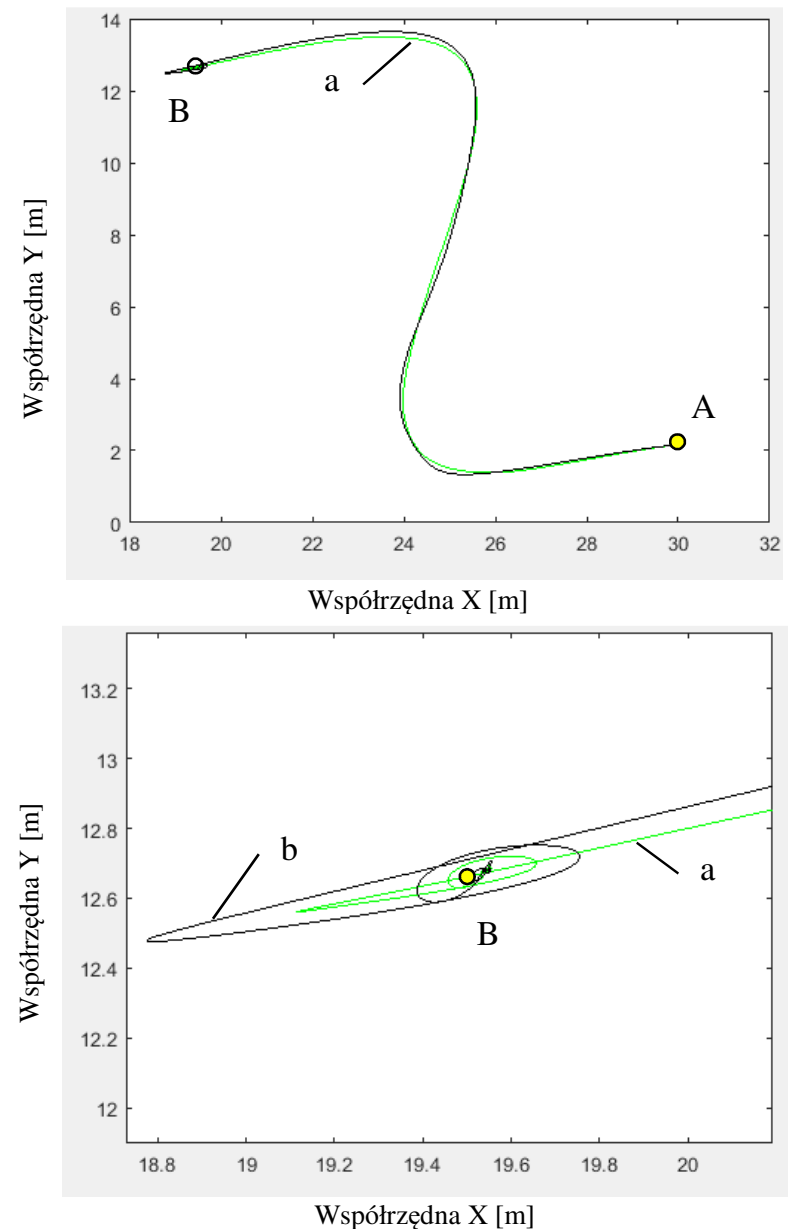

Rysunek 10. Porównanie trajektorii otrzymanych z symulacji dla ruchu sinusoidalnego trwajacego: a) 70 s (linia koloru zielonego) i b) 40 s (linia koloru czarnego) 


\section{Podsumowanie i wnioski}

W pracy przedstawiono model symulacyjny żurawia wieżowego stacjonarnego z wysięgnikiem wodzakowym, górnoobrotowego, który opracowano w programie ADAMS. Omówiono sposób połączenia modelu symulacyjnego z programem Matlab/Simulink, a następnie wyjaśniono zasady opracowania w tym programie modelu układu regulacji ruchami roboczymi żurawia. Symulacje numeryczne przenoszenia ładunku przeprowadzono dla dwóch trajektorii (prostoliniowej i sinusoidalnej). Analizowano skuteczność zaprojektowanego układu regulacji w odwzorowaniu zadanych trajektorii dla dwóch znacznie różniących się prędkości ruchów roboczych.

Stwierdzono, że zaprojektowany układ regulacji pozwala uzyskać dobre dopasowanie trajektorii będących wynikiem pracy tego układu do trajektorii zadanych. Nieco gorzej układ regulacji radzi sobie z zapewnieniem ograniczenia wahań ładunku po osiągnięciu punktu końcowego trajektorii. Rozwiązanie tego problemu będzie wymagało dopracowania zaprojektowanego układu regulacji, na przykład poprzez zastosowanie odpowiednio dopasowanych do modelu symulacyjnego strategii sterowania zapewniających minimalizację wahań ładunku [11].

\section{LITERATURA}

1. SKRZYMOWSKI W.: Obsługa żurawi wieżowych. KaBe, Krosno 2008.

2. ŠANDOR I., JADRANKO M., FETAH K.: Sequential distributed predictive control of a 3D tower crane. Control Engineering Practice, 79 (2018) 22-35.

3. UCHIYAMA N.: Robust control of rotary crane by partial-state feedback with integrator. Mechatronics, 19 (2009) 1294-1302.

4. NEUPERT J., ARNOLD E., SCHNEIDER K., SAWODNY O.: Tracking and anti-sway control for boom cranes. Control Engineering Practice, 18 (2010) 3144.

5. ROSENFELD Y.: Automation of existing cranes: from concept to prototype. Automation in Construction, 4 (1995) 125-138.

6. LEE G., CHO J., HAM S., LEE T., LEE G., YUN S., YANG H.: A BIM- and sensor-based tower crane navigation system for blind lifts. Automation in Construction, 26 (2012) 1-10.

7. SPASIĆ I.: https://cad-unigraphics-projects.blogspot.com/2011/07/tower-crane3d-model-free-cad-download.html (dostęp: 11.2018).

8. BORKOWSKI W., KONOPKA S., PROCHOWSKI L.: Dynamika maszyn roboczych. Wydawnictwa Naukowo-Techniczne, Warszawa 1996.

9. CRAIG J. J.: Wprowadzenie do robotyki. Mechanika i sterowanie. Wydawnictwa Naukowo-Techniczne, Warszawa, 1995.

10. TCHOŃ K., MAZUR A., HOSSA R., DULĘBA I., MUSZYŃSKI R.: Manipulatory i roboty mobilne. Modele, planowanie ruchu, sterowanie. Akademicka Oficyna Wydawcza PLJ, Warszawa, 2000.

11. Praca zbiorowa pod red. TROMBSKIEGO M.: Algorytmy sterowania cyklem pracy żurawia teleskopowego. Wydawnictwo Akademii TechnicznoHumanistycznej w Bielsku-Białej, Bielsko-Biała 2003. 